\title{
Complex Partial Seizure
}

National Cancer Institute

\section{Source}

National Cancer Institute. Complex Partial Seizure. NCI Thesaurus. Code C155290.

A seizure that originates in one area of the brain that affects consciousness. 